\title{
Analisis Kritik Terhadap Model Kipas; Konseling Intensif Progresif Adaptif Struktur
}

\author{
Rezki Hariko ${ }^{1} \&$ Ifdil Ifdil ${ }^{2}$ \\ ${ }^{12}$ Fakultas Ilmu Pendidikan, Universitas Negeri Padang \\ $\equiv$ e-mail: hariko@konselor.org
}

\begin{abstract}
Abstratc
Bimbingan dan konseling merupakan salah satu komponen integral dalam pendidikan yang eksistensinya dari waktu ke waktu semakin dibutuhkan. Sayangnya, pelaksanaan bimbingan dan konseling selama ini masih mengadopsi secara membabi-buta rumusan yang dibuat oleh para ahli yang berlandaskan pada falsafah Barat. Konseling Intensif Progresif Adaptif Struktur (KIPAS) yang dikreasikan oleh Andi Mappiare-AT muncul sebagai salah satu dari sedikit jenis bimbingan dan konseling yang berlandaskan pada budaya Nusantara. Fokus penulisan artikel ini mencakup deskripsi dan analisis kritis terhadap Model KIPAS; uraian tentang kontribusi Model KIPAS terhadap pengembangan diri dan penyelesaian masalah konseli, dan kontribusi terhadap citra konseling Indonesia. Basis budaya yang diusung oleh Model KIPAS menjadi keunggulan utama model ini, menjadikannya sangat efektif untuk diaplikasikan dalam pelayanan bimbingan dan konseling Indonesia. Disamping itu, terdapat beberapa kritikan terhadap Model KIPAS, khususnya terkait dengan masih minimnya kajian mendalam tentang karakteristik manusia Indonesia, dan "pemangkasan" tahapan konseling. Sebagai model yang berbasis pada budaya bangsa, Model KIPAS perlu mendapat dukungan dan upaya pengembangan lebih lanjut dari segenap praktisi dan akademisi bidang bimbingan dan konseling.
\end{abstract}

Keyword: analisis kritik, konseling, KIPAS.

Copyright (C) 2017 IICET (Indonesia) - All Rights Reserved

Indonesian Institute for Counseling, Education and Theraphy (IICET)

\section{PENDAHULUAN}

Sebagai jenis pelayanan yang memfokuskan diri pada upaya-upaya pemberian bantuan secara psikologis terhadap individu dan kelompok, keberadaan dan unjuk kerja bimbingan dan konseling semakin dibutuhkan dari waktuke waktu. Perkembangan teknologi informasi dan globalisasi yang terjadi dewasa ini menempatkan siswa pada posisi yang sangat rentan terhadap sejumlah pengaruh negatif dari perkembanan tersebut. Berbagai perilaku menyimpang yang dilakukan oleh siswa mulai menjamur ke permukaan dan dapat dengan mudah diketahui dari pemberitaan di media masa, baik cetak maupun elektronik. Permasalahanpermasalahan tersebut tidak saja terjadi pada siswa-siswa sekolah menengah, namun juga telah menjalar pada siswa sekolah dasar.

Permasalahan-permasalahan seperti telah disinggung membutuhkan perhatian yang serius dari semua pihak, baik keluarga, sekolah, dan masyarakat.Dalam hal ini, konselor sebagai pendidik yang mengampu pelayanan bimbingan dan konseling yang berada di sekolah merupakan pihak penting yang diharapkan berkontribusi terhadap pengentasan berbagai permasalahan pribadi dan pengembangan diri siswa.Menurut Gibson \& Mitchel (2011) bimbingan dan konseling merupakan pelayanan bantuan untuk peserta didik baik individu atau kelompok agar mandiri dan berkembang secara optimal dalam hubungan pribadi, sosial, belajar, karir; melalui berbagai jenis layanan dan kegiatan pendukung atas dasar norma-norma yang berlaku. Konselor sebagai pelaksanan bimbingan dan konseling membantu siswa yang tengah bergulat dengan berbagai permasalahan pribadi; sosial, belajar, karir, dan aspek lainnya (Hariko, 2017). Permasalah-permasalahan 
tersebut cenderung bukan merupakan suatu konsep yang tunggal, melainkan saling terkait dengan berbagai aspek dan seringkali juga melibatkan individu dan kelompok lain.

Upaya-upaya bantuan yang dilakukan dalam rangka pengembangan diri dan pengentasan permasalahan pribadi siswa pada dasarnya telah dilakukan oleh konselor di sekolah. Berbagai perspektif teori dan pendekatan yang telah dipelajari pada jenjang pendidikan akademik dan profesi, diaplikasikanke dalam pelaksanaan praktik pelayanan.Pada umumnya, lembaga-lembaga pendidikan penghasil konselor sekolah membelajarkan berbagai perspektif teori dan pendekatan yang telah lama dicetuskan dan dipraktikkan oleh ahli konseling yang menganut falsafah Barat. Bimbingan dan konseling Indonesia sudah sejak lama merasa aman, nyaman dan bahkan asyik bekerja dengan falsafah konseling Barat (Mappiare, 2013a:39).Bimbingan dan konseling selama ini bekerja di bawah pengaruh kental pandangan-pandangan Barat, seperti: Psychodynamic, Cognitive,Behavior, Humanistic dan Person-Centered, Rational-Emotive, Gestalt, SystemicRelation (Shertzer \& Stones, 1974; Cottone, 1992; McLeod, 2009; Neukrug, 2012) dan lain sebagainya. Selama ini, falsafah konseling Baratcenderung dijadikan sebagai referensi utama dan bahkan satu-satunya dalam setiap penyelenggaraan bimbingan dan konseling terhadap siswa.

Fakta yang terjadi pada perkembangan bimbingan dan konseling Indonesia seperti telah disinggung, pada prinsipnya merupakan sesuatu yang sangat memprihatinkan. Bagaimanapun, dapat diyakini bahwa falsafah yang dianut oleh pandangan Barat berbeda dan bahkan pada beberapa aspek bertentangan dengan falsafah hidup masyarakat Indonesia. Dalam hal ini, konselor bermartabat tidak boleh bekerja dengan meminjam falsafah yang telah dibangun oleh orang lain (Shertzer\& Stones, 1974: 150; Mappiare, 2013a: 39). Konselor harus mampu mengembangkan kesadaran nilai sendiri tentang manusia, dirinya dan konseli yang berada di wilayah tanggung jawab kerjanya.

Tidak dapat dipungkiri, Indonesia merupakan negara besar yang terdiri dari ribuan pulau besar dan kecil yang didiami oleh masyarakat dari berbagai macam agama, suku, budaya, dan masyarakat hukum adat. Wilayah geografis Indonesia didiami oleh sejumlah suku besar, yaitu: Jawa, Minangkabau, Batak, Bugis, Madura (Nizhamul, 2009), serta ratusan suku-suku lainnya.Masing-masing suku, budaya, dan masyarakat hukum adat tersebut hidup dan berkembang berdasarkan kesadaran nilai yang berbeda-beda, unik dan cenderung menganut falsafah hidup masyarakat Timur yang penuh tata karma dan agamis. Hal yang menarik dari keberagaman tersebut, perbedaan budaya masyarakat Indonesia mampu diikat dalam suatu kesatuan dalam bingkai Negara Kesatuan Republik Indonesia.

Sebagai tenaga profesional, konselor harus secara terus-menerus memperbarui dan memperluas pengetahuan tentang manusia, bidang bimbingan dan konseling serta mengevaluasi pelayanan. Hal ini perlu dilakuka, terutama karena sifat yang diterapkan dari pekerjaan konselor mempengaruhi kehidupan sehari-hari dari banyak orang. Terkait dengan hal ini tentu saja seorang konselor dalam memperbarui, memperluas dan mengaplikasikan keilmuannya harus senantiasa berpegang teguh pada penerapan nilai-nilai yang sesuai dengan nilai kemanusiaan yang dianut secara luas oleh masyarakat (Hariko, 2016:119). Konselor diharapkan tidak sekedar mempelajari dan mempraktikkan teori dan pendekatan yang dikemukakan oleh Barat, namun juga mampu merumuskan gubahan-gubahan tersendiri tentang bimbingan dan konseling Indonesia dengan berlandasakan pada kekhasan budaya Nusantara.

Pluralitas yang terdapat pada masyarakat Indonesia sejatinya mendorong para praktisi dan akademisi bidang bimbingan dan konseling untuk mengkreasikan model pelayanan yang sesuai dengan budaya Bangsa. Beberapa pakar telah mencoba merumuskan model bimbingan dan konseling yang disesuaikan dengan karakteristik manusia Indonesia, meskipun dalam jumlah yang sangat sedikit apabila dibandingkan dengan beragamnya spesifikasi karakteristik masyarakat Indonesia. Beberapa model dimaksud, yaitu: Model Konseling Intensif dan Progresif yang Adaptif terhadap Struktur (Mappiare, Mappiare-AT, 2013a; 2013b; 2017), dan Konseling Pancawaskita (Prayitno, 1998). Pada kajian ini dilakukan pembahasan dan analisis kritis terhadap Model Konseling Intensif dan Progresif yang Adaptif terhadap Struktur (KIPAS).

Fokus bahasan pada artikel ini disajikan dalam bentuk uraian, tentang: Deskripsi Model KIPAS, Analisis kritis terhadap Model KIPAS secara mendalam berdasarkan model yang sudah ada, dan menyajikan hasil analisis tersebut berupa rumusan tentang kekuatan/kelebihan, tanggapan dan kritikan yang bersifat konstruktif dan Kontribusi Model KIPAS terhadap penyelesaian masalah konseli dan citra konseling Indonesia

\section{METODOLOGI}

Jenis pendekatan yang digunakan pada kajian ini yaitu pendekatan kualitatif tipe riset karya seni dan kritisisme. Menurut Mappiare-AT (2013c:97) tipe riset karya seni dan kritisisme merupakan jenis tipe riset kualitatif berdasarkan pada sifat analisisnya, dimana tipe ini lebih menonjol pada strategi analisis kritik 
dengan tujuan untuk mendeskripsikan dan menafsirkan makna suatu karya guna menjelaskan suatu fenomena terkait teori tertentu, mengkritiknya atau mengkritik teori, atau membangun teori. Karya yang dikiritisi pada kajian ini adalah Model Konseling Intensif dan Progresif yang Adaptif terhadap Struktur (KIPAS) yang dikreasikan oleh Andi Mappiare-AT (Mappiare-AT, 2013a; 2013b; 2017). Model yang dikreasikan tersebut merupakan salah satu dari sedikit jenis model layanan bimbingan dan konseling Indonesia yang berbasiskan pada budaya Nusantara.

Berdasarkan definisi kata, istilah analisis kritik berasal dari dua suku kata yaitu analisis dan kritik. Kata analisis didefinisikan sebagai penyelidikan terhadap suatu peristiwa (karangan, perbuatan, dan sebagainya) untuk mengetahui keadaan yang sebenarnya (sebab-musabab, duduk perkaranya, dan sebagainya), dan kata kritik didefinisikan sebagai kecaman atau tanggapan, kadang-kadang disertai uraian dan pertimbangan baik buruk terhadap suatu hasil karya, pendapat, dan sebagainya, dan penguraian suatu pokok atas berbagai bagiannya dan penelaahan bagian itu sendiri serta hubungan antarbagian untuk memperoleh pengertian yang tepat dan pemahaman arti keseluruhan(Setiawan, 2016). Menurut Hassoubah (2007) berpikir kritisadalah kemampuan memberi alasan secara terorganisasi danmengevaluasi kualitas suatu alasan secara sistematis. Berdasarkan beberapa definisi tersebut, dapat disimpulkan bahwa analisis kritik merupakan upaya penyelidikan terhadap suatu karangan atau karya untuk mengetahui sesuatu dengan jalan mengemukakan tanggapan, uraian, pertimbangan, berdasarkan hasil penelaahan secara mendalam terhadap karangan atau karya tersebut.

Masalah yang hendak dikritisi dan dipahami dalam riset karya seni dan kritisisme dapat digolong pada beberapa tema, sebagai berikut: (1) masalah kritik sosial, (2) masalah kritik seni murni, (3) masalah kritik normatif kemasyarakatan, dan (4) masalahan kritik saintifik/keilmuan (Mappiare-AT, 2013c:102). Dalam hal ini Model KIPAS merupakan salah satu bentuk karya dalam bidang saintifik/keilmuan yang dirancang untuk dimanfaatkan pada pelayanan bimbingan dan konseling Indonesia, terutama pelayanan bimbingan dan konseling di sekolah. Adapun lagkah-langkah pelaksanaan riset karya seni dan kritisisme meliputi: (1) peninjauan dan pengamatan terhadap suatu karya, (2) perumusan masalah menurut kategori pilihan, (3) pengkajian secara mendalam, identifikasi dan deskripsi fenomena menonjol, (4) membaca secara dekat (closereading), dan (5) refleksi dan penyimpulan (Mappiare-AT, 2013c:103).

\section{HASIL DAN PEMBAHASAN}

Perkembangan bimbingan dan konseling di Indonesia belumlah dapat dibilang mengalami kemajuan. Bimbingan dan konseling Indonesia selama ini lebih kepada bertindak sebagai konsumen dari buah pikir para pemikir Barat. Pandangan-pandangan yang dirumuskan berdasarkan karakteristik konselor dan konseli Barat, diterapkan secara paksa terhadap konselor dan konseli Indonesia. Menurut Corey (1991) konseling model Barat memiliki banyak keterbatasa apabila diterapkan pada populasi khusus tertentu dan kelompok minoritas. Sejalan dengan itu, menurut Pederson (1991) asumsi yang dibuat oleh konselor dan konseli yang berbeda latar belakang budaya mengakibatkan konseling yang bias dari segi kultural dan menyebabkan terjadinya penggunaan layanan kesehatan mental yang kurang memadai. Pendapat-pendapat ahlitersebut sebenarnya dapat menjadi jawaban terhadap pertanyaan-pertanyaan yang terkait dengan tidak optimalnya peran bimbingan dan konseling dalam membantu siswa dalam pengembangan diri dan pengentasan permasalahannya.

Masyarakat Indonesia dengan pluralitas yang sangat tinggi memiliki kebutuhan dan potensi permasalahan pribadi yang sangat berbeda apabila dibandingkan dengan masyarakat Barat. Hal ini tentu saja tidak terlepas dari perbedaan latar belakang historis antara masyarakat Barat dengan masyarakat Indonesia. Pemahaman terhadap kondisi kekiniankonseli tentu saja tidak dapat serta merta dipisahkan dari kondisi yang mendahuluinya pada masa yang telah lampau. Hal ini selaras dengan pendapat Kartodirdjo(1968) bahwa masa sekarang sebenarnya tidak lain merupakan kelanjutan atau perpanjangan dari masa lampau, dan berbagai macam keadaan dan persoalan dewasa ini tidak mungkin dimengerti betul-betul kalau tidak diketahui latar belakang historisnya, yaitu asal mulanya dan perkembangannya pada waktu yang lalu. Pemahaman menyeluruh tentang kondisi budaya konseli, diyakini dapat membantu konselor dan konseli dalam upaya pengembangan diri dan/atau pengentasan permasalahan pribadi konseli.

Pada bagian berikut dibahas tentang deskripsi singkat Model KIPAS, Analisis Model KIPAS berdasarkan berbagai pendekatan, dan kontribusi KIPAS terhadap penyelesaian masalah konseli dan meningkatkan citra konseling Indonesia. Pembahasan tersebut dilakukan untuk memenuhi kelima langkah pelaksanaan riset karya seni dan kritisisme (Mappiare-AT, 2013c:103) seperti telah disinggung pada bagian metode. 


\section{Deskripsi Singkat Model KIPAS}

Sebagai rumusan model konseling, Model KIPAS memiliki delapan unsur pokok (Mappiare, 2013a; 2013b; 2017), yaitu: (1) nama model yaitu Konseling Intensif dan Progresif yang Adaptif terhadap Struktur (KIPAS), (2) posisi diri atau kondisi fasilitatif konselor adalah sebagai kawan bagi siswa/konseli, inovator, pamong, abdi dan suporter, (3) tema-tema bahasan meliputi: karakter, identitas, pekerjaan, akademik dan sosial, (4) langkah-langkah konseling, yaitu: kabar gembira, integrasi data dan internalisasi, perencanaan tindakan, aktualisasi rencana (tindakan), dan selebrasi/sertifikat untuk konseli, (5) kategori teknik komunikasi meliputi: kata dukungan, interpretasi, pemantulan, arahan, saripati, (6) aset terabaikan konseli (kondisi awal konseling) dilabelkan menjadi: keterampilan terpendam dan tersia-siakan, intelektual terpendam dan tersiasiakan, power tersimpan/ terbuang sia-sia, asosiatif berlebihan, dan sensitif simpang orientasi, (7) aset ideal/terbarukan konseli (kondisi akhir yang diharapkan, tujuan konseling) dinamakan: kecakapan hidup produktif, intelijen/cerdas berfikir kritis, piawai/penuh daya, analis aktif dan realistis, dan sensitif pada norma/nilai, dan (8) strategi modifikasi konseling bernama: kelola diri, imunisasi diri, permainan, analisis diri, dan sarasehan.

Rumusan Model KIPAS hadir sebagai upaya untuk mewujudkan profil martabat mulia konselor Indonesia, yaitu: (1) profil martabat yang melekat dalam falsafah, (2) profil martabat dalam pribadi konselor, (3) profil martabat dalam basis budaya bangsa, (4) profil martabat dalam desain model, dan (5) profil martabat dalam hasil-hasil nyata konseling (Mappiare, 2013a). Menurut Model KIPAS (Mappiare, 2013a) martabat konselor dan sekaligus konseli Indonesia sudah termaktub pada Bhineka Tunggal Ika sebagai semboyan baku yang bernilai mulia dan ampuh, Burung Garuda sebagai lambang Negara, Pancasila sebagai dasar Negara, dan Sangsaka Merah Putih. Hal ini selaras dengan Model Pancawaskita (Prayitno, 1998:36) yang memposisikan Pancasila sebagai salah satu faktor yang mempengaruhi perkembangan dan kehidupan individu/konseli.

Model KIPAS menawarkan profil martabat konselor dalam kepribadian manusia Indonesia ideal yang memiliki kualitas karakter "manusia Indonesia seutuhnya" (Syam, 1988), yaitu: (1) memiliki komposisi kompetensi paedagogik, sosial, pribadi dan profesional yang pantas; seimbang, selaras dan serasi, (2) dalam bekerja bersama sejawat sebagai subjek kolegial memposisikan diri menurut pandangan asli Indonesia, yaitu: konselor Indonesia di antara kolega dan teman kerja mengutamakan kesetaraan, menghindari dominasi, kontrol dan pemaksaan, dan (3) memiliki perilaku belajar sepanjang hayat (Mappiare, 2013a).

Basis konstruksi model KIPAS (Mappiare, 2013a; 2013b; 2017) adalah budaya Nusantara dengan asumsi bahwa: (1) semua siswa berhak mendapatkan kabar gembiramengenai dirinya, pelayanan yang mendatangkan rasa gembira dalam konseling, menguntungkan dan membanggakan diri dan orangtuanya, (2) secara sosial dan psikologis konseli tidak diposisikan sebagai sasaran layanan, sebagai objek layanan, melainkan sebagai subjek, (3) siswa/konseli Indonesia dipandang sebagai individu yang memiliki potensi positif, dan (4) dalam zona kerja, konseli selayaknya dilabelkan sebagai kawan kerja bukannya sebagai konseli yang ditangani (Mappiare, 2013a; 2013b; 2017). Basis konstruksi yang dimiliki Model KIPAS tersebut sejalan dengan pendapat Lago (2006) konselor dituntut memiliki kemauan dan kemampuan untuk menjelajahi asal-usul budaya dan ras mereka sendiri, dimana hal ini merupakan salah satu tantangan terbesar dalam konseling. Tanpa penjelajahan dan pengenalan terhadap budaya, pelaksanaan konseling diyakini tidak akan membuahkan hasil yang optimal bagi pengembangan diri dan pengentasan permasalahan konseli.

Beberapa model konseling menawarkan berbagai peristilahan dalam istilah asing sesuai dengan tempat perumusan model tersebut. Dalam hal ini Model konseling KIPAS (Mappiare, 2013a; 2013b; 2017) disusun dengan peristilahan yang dikenal, tidak rumit, tidak banyak istilah asing, pembatasan jumlah konsep, istilah dan akronim yang sulit atau baru. Konselor hanya perlu mengingat satu akronim pokok, yaitu KIPAS. Tematema pembahasan konseling, langkah pelaksanaan konseling, teknik, istilah untuk kondisi awal konseling dan kondisi akhir yang diharapkan atau tujuan konseling, dan strategi modifikasi konseling menurut Model KIPAS diuraikan dari kepanjangan model itu sendiri.

\section{Analisis kritik terhadap Model KIPAS}

Proses analisis kritik terhadap Model KIPAS dilakukan berdasarkan beberapa contoh penjabaran teori yang dilakukan oleh ahli. Corey (1991) menjabarkan beberapa teori dan praktik konseling berdasarkan sub bahasan tentang konsep kunci teori, proses konseling, serta aplikasi teknik dan prosedur. Cottone (1992) menjabarkan beberapa teori dan praktik konseling berdasarkan sub bahasan tentang dasar teori, prosedur umum, dan teknik-teknik khusus. Prayitno (1998) menjabarkan rumusan teori dan praktik konseling berdasarkan sub bahasan tentang hakikat manusia, individu dan perkembangannya, tingkah laku dan kepribadian, permasalahan individu, konsep kunci teori dan proses konseling. Berdasarkan beberapa contoh rumusan teori yang dikemukakan ahli tersebut, langkah pertama analisis kritis terhadap Model KIPAS 
mencakup upaya penyelidikan dan penelaahan terhadap dasar filosofis dan konsep kunci, proses, aplikasi teknik dan prosedur, permasalahan atau tema-tema, dan hasil akhir yang diharapkan. Analisis terhadap aspekaspek tersebut dapat saja diuraikan tidak secara berurutan dan tumpang tindih.

Model KIPAS secara gamblang berupaya untuk melepaskan diri dari ketergantungan bimbingan dan konseling Indonesia terhadap pandangan Barat. Penyelenggaraan bimbingan dan konseling Indonesia harus didasarkan atas realitas manusia Indonesia. Menurut Mappiare-AT (2013a; 2013b; 2017) realitas manusia Indonesia adalah menjunjung tinggi dan meyakini yang sudah "ada", yaitu sudah ada di sana, sudah digali dari bumi pertiwi, dari akar budaya bangsa Indonesia, dalam bentuk yang utuh atau bulat, sudah diangkat dan dicapai kata sepakat. Karakter dan jati diri manusia Indonesia tergambar pada lambang dan semboyan utama Negara Kesatuan Republik Indinesia, yaitu: semboyan Bhineka Tunggal Ika, Burung Garuda, Pancasila, dan Sang-saka Merah Putih.

Perumusan Model KIPAS berasal dari landasan ilmu yang interdisipliner, tidak bersandar secara penuh terhadap ilmu psikologi atapun satu ilmu lainnya. Hal tersebut dapat tergambar diantaranya dari penggunaan beberapa istilah yang berasal dari ilmu sosiologi, biologi, dan kesehatan. Menurut Glanz (Hansen, dkk., 1982) konseling bersifat interdisipliner yaitu mengaplikasikan konsep-konsep dari ilmu psikologi, sosiologi, antropologi, pendidikan, ekonomi dan filsafat. Sejalan dengan hal tersebut, menurut (Gibson \& Mitchell, 2008)konseling sebagai suatu ilmu memiliki ikatan disipliner dengan bidang psikologi, sosiologi, antropologi, biologi, kesehatan dan ilmu lainnya. Pengembangan teori dan praktik konseling tidak boleh berpijak pada salah satu disiplin ilmu. Berdasarkan pengetahuan luas pengkreasi tentang berbgai disiplin ilmu tersebut, gubahan Model KIPAS memiliki unsur-unsur model konseling yang lengkap, sistematis dan dapat dipahami dengan mudah.

Namun demikian, penjabaran tentang manusia menurut pandangan Model KIPAS masih terkesan sangat general, dan cenderung mengabaikan perbedaan individu dan kelompok-kelompok budaya yang ada di Indonesia. Pencirian karakteristik manusia Indonesia berdasarkan lambang dan semboyan utama Negara Kesatuan Republik Indonesia, yaitu: semboyan Bhineka Tunggal Ika, Burung Garuda, Pancasila, dan Sangsaka Merah Putih, dikhawatirkan akan membawa konselor dan konseli pada penelahaan yang dangkal dan general tentang konsep konseli sebagai individu yang berbeda antar satu dan lainnya. Oleh karena itu, perlu dilakukan penjabaran yang lebih mendalam tentang keempat karya mulia bangsa yang disebutkan, sehingga tampak kekhasan penerapannya pada masing-masing cakupan budaya yang lebih kecil yang tergambar dalam bentuk struktur dan perkembangan kepribadian manusia.

Beberapa teori terdahulu telah mengemukakan penjelasan yang rinci tentang struktur dan perkembangan pribadi manusia. Menurut pandangan Barat kepribadian terdiri dari tiga sistem: komponen biologi yaitu id, komponenpsikologiyaitu ego, komponen sosial yaitusuperego, dan menempatkan insting pada posisi sentral (Psikoanalitik); manusia dimotivasi oleh faktor sosial, persepsi dan interpretasi terhadap masa lalu serta dan pengaruh yang berkelanjutan (Psikososial Adlerian); manusia merupakan makhluk yang selalu dalam keadan transisi, berkembang, membentuk diri dan menjadi sesuatu (eksistensial); manusia cenderung berkembang secara positif dan konstruktif apabila tercipta suasana menghormati dan mempercayai (terpusat pada pribadi); individu dapat menangani sendiri problema hidup mereka sendiri secara efektif (Gestalt); manusia memiliki tiga pola ego state yang terpisah yaitu: ego state adult, ego state parent dan ego state child (Analisis Transaksional); memiliki kecenderungan berfikir secara rasional dan/atau tidak rasional (Rasional-Emotif); perilaku manusia digerakkan untuk memenuhi kebutuhan psikologis dan fikologis (Realitas), dan lain sebagainya (Corey, 1991; Cottone, 1992; Geldard \& Geldard, 2005; Palmer, 2010; Gibson \& Mitchel, 2011).

Generalitas pandangan model KIPAS juga tergambar dengan tidak disebutkannya secara spesifik contoh konseli sampel uji ilmiah yang pernah diterapkan. Bagaimapun Indonesia merupakan Negara yang sangat plural. Satu daerah memiliki bermacam-macam suku, dan masing masing suku dalam satu daerah yang kecil seringkali memiliki corak khas yang unik dan berbeda dalam kelompok-kelompok kecil. Dalam hal ini empat karya mulia yang menjadi landasan filosofis Model KIPAS lebih dipandang sebagai sarana pemersatu yang memudahkan interaksi dan komunikasi antar suku.Di dalamnya terdapat gambaran umum tentang jati diri dan nilai yang dianut oleh manusia Indonesia, tetapi belum bisa secara spesifik menggambarkan karakteristik individu manusia Indonesia.

Individu yang potensial memanfaat pelayanan konseling pada Model KIPAS cenderung terkesan sangat sempit, yaitu hanya untuk siswa. Lebih jauh, siswa yang paling memungkinkan untuk pengaplikasian Model KIPAS adalah siswa sekolah menengah. Model KIPAS mendorong siswa secara mandiri mengakumulasikan data diri pribadi sebagai salah satu modal dasar untuk mengikuti sesi wawancara konseling. Hal ini tentunya merupakan sesuatu yang mustahil dilakukan oleh siswa pada jenjang Sekolah Dasar dan tingkat yang lebih rendah dari itu. Menurut (Gibson \& Mitchell, 2011) tempat konselor bekerja 
sangat luas, mencakup: lingkup pendidikan yaitu sekolah dasar, sekolah menengah dan pendidikan tinggi; komunitas dan lembaga-lembaga kesehatan mental, dan praktik pribadi. Model KIPAS tentunya akan mengalami kendala apabila diaplikasikan pada konseli yang berada di luar lembaga pendidikan (sekolah menengah), terutama pada praktik pribadi.

Pada prinsipnya, teknikatau keterampilan konselor yang ditawarkan oleh Model KIPAS cukup variatif dan komprehensif, meliputi: teknik komunikasi yaitu: kata dukungan, interpretasi, pemantulan, arahan, saripati; dan strategi modifikasi konseling bernama: kelola diri, imunisasi diri, permainan, analisis diri, dan sarasehan. Dalam hal ini dapat dikemukakan bahwa teknik komunikasi yang digunakan merupakan representasi dari teknik umum, dan strategi modifikasi konseling merupakan teknik khusus. Menurut Hariko (2017) penyelenggaraan konseling yang efektif memanfaatkan sejumlah keterampilan yang tepat dengan spesifikasi kebutuhan dan permasalahan konseli, di mana penguasaan keterampilan komunikasi oleh konselor secara langsung berkorelasi dengan efektifitas penggunaan sejumlah keterampilan konseling lainnya.

Meskipunteknik dan keterampilan yang ditawarkan Model KIPAS sudah cukup variatif, teknik-teknik dan keterampilan konselor yang ditawarkan olehModel KIPAS lebih lanjut perlu dikembangkan dan disesuaikan dengan kebutuhan pembahasan permasalahan konseli. Neukrug (2012) menguraikan terdapat empat pengelompokan utama keterampilan yang digunakan konselor dalam proses konseling, yaitu: (1) keterampilan dasar terdiri dari mendengarkan, empati dan pemahaman mendalam, serta diam; (2) keterampilan yang biasa digunakan terdiri dari pertanyaan, pengungkapan diri, pemodelan, afirmasi dan dorongan, serta menawarkan alternatif, memberikan informasi, dan memberikan saran; (3) keterampilan lanjutan yang biasa digunakan terdiri dari konfrontasi, penafsiran dan kolaborasi; (4) keterampilan konseling lanjutan dan spesialis terdiri dari penggunaan metafora, hipnosis, keterampilan strategis, metode restrukturisasi kognitif, narasi dan cerita, terapi sentuhan, paradoxical intention, bermain peran, berbagai teknik visualisasi, dan sebagainya.

Keberadaan teknik yang bervariasi memungkinkan konselor untuk menjelajahi informasi konseli secara meluas dan mendalam. Menurut Nelson-Jones(2008: 12) keterampilan konselor dibagi atas lima tujuan yang berbeda, yaitu: memberi konseli perasaan difahami dan diafirmasi, mengelola situasi bermasalah, mengelola masalah, mengubah keterampilan-keterampilan buruk yang menciptakan masalah, dan mewujudkan perubahan falsafah hidup. Beberapa contoh teknik yang digunakan dalam penyelenggaraan konseling seperti: scalling, exeptions, problem-free talk, miracle question, flagging the minefield (konseling pendek terfokus-solusi), I-message, acting as if. Spittiing in the soup, mutual storytelling, paradoxical intention (Adlerian atau Psikodinamik), empty chair, body movement and exaggeration, role reversal (Gestal dan Psikodrama), self-disclosure, confrontation, motivational interviewing, strength Bombardment (Humanistik-fenomenologis), self-talk, reframing, thought stopping, cognitive restructuring, rational emotie behavior therapy, bibliotherapy, journaling, systematic desensitization, stress inoculation raining (KognitifBehavioral), modeling, behavioral rehearsal, role play (Belajar Sosial) (Erford, 2015).

Berikutnya, penghilangan tahap 1, tahap 2, dan tahap 3 pada Model KIPAS (Mappiare-AT, 2013b), seperti yang terdapat pada wawancara konseling model konvesional memiliki sejumlah konsekuensi negatif. Dikhawatirkan proses konseling yang diselenggarakan terjebak menjadi pembicaraan biasa, pembahasan diri klien tidak terlalu mendalam. Proses konseling yang terlalu pendek mengurangi kemungkinan konselor untuk mendengarkan pembicaraan konseli secara panjang lebar dan mendalam. Menurut Geldard \& Geldard (2005:15) mendengarkan merupakan cara yang paling penting bagi konselor untuk memenuhi kebutuhan konseli, karena seringkali konseli dapat merasa lebih baik hanya karena dia mendapatkan kesempatan untuk mengungkapkan permasalahan terhadap orang lain yang siap untuk mendengarkan. Tahap 1, tahap 2, dan tahap 3 seperti terdapat pada konseling konvensional masih sangat diperlukan, terutama terhadap konseli pada sesi konseling awal, konseli-konseli yang dirujuk, dan konseli-konseli yang datang dengan sejumlah pembicaraan awal yang membutuhkan penjelajahan mendalam dari konselor.

Tahap pertama dalam tahap konseling konvensional berisikan pengembangan hubungan atau komitmen. Tahap ini sangat beresiko untuk dihilangkan, terutama apabila berhadapan dengan konseli nonsiswa, konseli rujukan dan konseli untuk pertemuan perdana. Menurut Geldard \& Geldard (2005: 8) konseling melibatkan sebuah hubungan dan inti dari proses konseling adalah hubungan antara klien dan konselor. Beberapa pendekatan seperti pendekatan berpusat pada pribadi yang dikemukakan oleh Rogers (Hansen, Stevic \& Warner, 1982; Corey, 1991) secara khusus menekankan pentingnya pembinaan hubungan dari awalawal proses konseling.

Demikian juga halnya dengan tahap kedua dan ketiga pada tahap konseling konvensional yang berisikan tentang identifikasi dan penetapan model permasalahan konseli, dan penetapan arah dan tujuan konseling. Tahap ini penting untuk tetap dijalankan oleh konselor terutama pada proses konseling degan konseli non-siswa, konseli rujukan dankonseli untuk pertemuan perdana. Erford (2015) mengemukakan lima 
alasan yang mendasari pentingnya penetapan tujuan di awal hubungan konseling, yaitu: (1) penetapan tujuan di awal proses konseling mempengaruhi keseluruhan proses konseling, (2) tujuan konseling menyediakan target operasional kongkret dan memudahkan konselor-konseli mengatahui kemajuan konseling, (3) tujuan memberikan target yang menginisiasi terjadinya pergerakan/perubahan pada konseli, (4) tujuan yang dirancang dengan baik memungkinkan konselor untuk mengumpulkan berbagai pendekatan, intervensi, dan teknik yang paling efektif diaplikasikan terhadap konseli, dan (5) tujuan dapat dijadikan sebagai acuan untuk mengukur keberhasilan konseling.

Model KIPAS dinilai terlalu humanis dalam memandang klien yang tergambar pada langkah pertama sesi wawancara konseling, yaitu pemberian kabar gembira pada awal-awal sesi wawancara konseling. Setiap individu pada prinsipnya memang berhak memperoleh kabar gembira dalam konseli, yang menguntungkan dan membanggakan diri dan orangtuanya. Namun, pada banyak situasi besar kemungkinan konselor akan mengalami kesulitan untuk memberikan kabar gembira kepada setiap siswa-siswa yang masih sangat baru di sekolah, konseli rujukan ataupun konseli-konseli-konseli yang baru pertama kali melakukan sesi wawancara konseling. Kekacauan sistem data tentang siswa yang ada di sekolah, ketiadaan data yang dimiliki secara pribadi oleh siswa, dan perbedaan alasan-alasan individu mendatangi konselor dapat menyebabkan konselor kesulitan dalam mengaplikasikan langkah ini. Terkait dengan perbedaan alasan konseli menemui konselor, menurut Geldard \& Geldard (2005:7) orang datang menemui konselor biasanya ketika mereka merasa terganggu secara emosional, dan merasa bahwa mereka tidak bisa menangani persoalan mereka sendiri dan mencari penyelesaian dengan harapan menemukan solusi dan merasa lebih baik. Beberapa konseli lain mendatangi konselor dengan alasan untuk memperoleh sejumlah informasi, mendiskusikan sejumlah data yang diperoleh, atau untuk alasan-alasan sederhana lainnya.

Tema-tema yang ditawarkan Model KIPAS sudah cukup komprehensif, namun belum menyentuk aspek religiusitas atau bidang keberagamaan yang menjadi salah satu corak khas kondisi psikososial masyarakat Indonesia. Meskipun aspek religiusitas ini sudah termaktub dalam rumusan dan penjelasan Pancasila sila pertama, namun interpretasi masing-masing individu sangat berfariasi, sesuai dengan agama dan kepercayaan yang dianutnya. Beberapa permasalahan yang mengemuka dewasa ini justru berasal dari kesalahan dalam menginterpretasi Pancasila sila pertama dan penggeneralisasian terhadap setiap agama. Tema-tema yang menjadi bahasan konseling menurut Model KIPAS (Mappiare-AT, 2013a; 2013b; 2017) meliputi: karakter, identitas, pekerjaan, akademik dan sosial. Tema-tema tersebut memiliki kemiripan dengan konsep yang dikemukakan dalam pendefinisian bimbingan dan konseling oleh Gibson \& Mitchel (2011) yaitu hubungan pribadi, sosial, belajar, karir. Menimbang akan kompleksitas jenis dan tema permasalahan konseli, tema-tema pada Model KIPAS perlu lebih diperluas.

\section{Kontribusi KIPAS terhadap Penyelesaian Masalah Konseli dan Citra Konseling Indonesia.}

Layanan bimbingan dan konseling model KIPAS diyakini memiliki prospek masa depan yang cerah bagi pengentasan masalah konseli/siswa. Model konseling ini jauh lebih mudah untuk difahami dan diaplikasikan oleh konselor terhadap sejumlah konseli. Penyusunan model KIPAS yang dilakukan dengan berbasiskan pertimbangan nilai budaya bangsa diyakini akan cocok dengan karakteristik konselor, konseli dan permasalahan manusia Indonesia. Penggunaan peristilahan yang dikenal, tidak rumit, tidak banyak istilah asing, pembatasan jumlah konsep, istilah dan akronim yang sulit atau baru memudahkan konselor untuk mengaplikasikannya.

Berbeda degan model-model konseling konvensional yang cenderung abai terhadap pentingnya kerjasama dan kolaborasi antara konselor dengan semua elemen yang ada di sekolah, Model KIPAS terbuka terhadap hubungan kerjasama dan kolaborasi antar dan interprofesi, bersifat intensif dan adaptif terhadap struktur yang ada di sekolah(Mappiare, 2013a; 2013b; 2017. Konselor bekerjasama dengan segenap personil sekolah dan pihak-pihak lain yang terkait dalam menghimpun data konseli yang dibutuhkan bagi keefektifan proses konseling. Penerapan Model KIPAS memungkinkan konselor melayani sejumlah siswa dalam rentang waktu yang tidak terlalu panjang. Durasi pertemuan wawancara konseling yang cukup pendek memungkinkan seluruh siswa yang jadi tanggung jawab konselor dapat terlayani. Namun demikian, perlu ditekankan efisiensi penggunaan waktu tidak menjerumuskan pada proses konseling yang dangkal.

Eksistensi Model KIPAS secara langsung akan sangat mengangkat martabat konselor dan konseling Indonesia. Suatu citra bermartabat bagi konselor dan konseling Indonesia harus disandarkan pada konteks sosial-budaya Nusantara (Mappiare, 2013a; 2013b; 2017). Tidak dapat dipungkiri selama ini dan bahkan hingga sekarang bimbingan dan konseling Indonesia selalu berada dalam pengaruh kuat model-model konseling Barat. Praktisi dan akademisi pada bidang bimbingan dan konseling sangat nyaman bersandar pada 
model tersebut, tanpa ada upaya nyata untuk mengembangkan model sendiri yang sesuai dengan karakteristik manusia Indonesia. Potret kenyamana ini salah satunya tergambar dari sangat minimnya upaya untuk merumuskan model konseling yang menggali nilai-nilai budaya bangsa.

Kehadiran model KIPAS merupakan upaya mengukuhkan martabat konselor dan konseling Indonesia. Model KIPAS hadir sebagai pilihan pelaksanaan bimbingan dan konseling di sekolah yang mampu mengangkat citra konseling Indonesia. Model KIPAS menjadikan konseling Indonesia memiliki jati diri sendiri dan tidak bergantung kepada model-model Barat yang diciptakan tanpa mempertimbangkan budaya bangsa Indonesia. Pembangunan model KIPAS yang dilakukan melalui serangkaian kajian dan pengujian ilmiah, menjadikannya dapat diterima dan diaplikasikan di lapangan. Agar citra konseling Indonesia semakin bagus, perlu dilakukan upaya pengembangan secara terus-menerus terhadap gubahan model KIPAS. Di samping itu, perlu juga dilakukan pengembangan model-model konseling lain yang berbasis pada budaya Nusantara

\section{SIMPULAN DAN SARAN}

Berdasakan uraian tentang analisis kritik digambarkan sejumlah kelebihan, kelemahan/kritikdan kontribusi Model KIPAS. Sebagai salah satu dari sedikit Model konseling Indonesia yang berbasiskan pada budaya Nusantara, Model KIPAS hadir dengan penjelasan tentang unsur-unsur pokok Model konseling yang mudah dipahami. Model KIPAS disusun dengan peristilahan yang dikenal, tidak rumit, tidak banyak istilah asing, pembatasan jumlah konsep, istilah dan akronim yang sulit atau baru. Perumusan Model KIPAS berasal dari landasan ilmu yang interdisipliner yang tidak bersandar secara penuh terhadap ilmu psikologi.

Terlepas dari sejumlah keunggulan yang ditampakkannya, penjabaran tentang manusia menurut pandangan Model KIPAS masih terkesan sangat general, dan cenderung mengabaikan perbedaan individu dan kelompok-kelompok budaya yang ada di Indonesia. Model KIPAS struktur dan perkembangan pribadi manusiatidak dipaparkan secara spesifik. Individu yang potensial memanfaat pelayanan konseling pada Model KIPAS cenderung terkesan sangat sempit, yaitu siswa. Teknik-teknik dan ketarampilan konselor yang ditawarkan oleh Model KIPAS lebih lanjut perlu dikembangkan dan disesuaikan dengan kebutuhan pembahasan permasalahan konseli.

Pemangkasan tahap 1, 2, dan 3 seperti yang terdapat pada wawancara konseling model konvesional memiliki sejumlah konsekuensi negatif. Tahap pertama dalam tahap konseling konvensional berisikan pengembangan hubungan atau komitmen, Demikian juga halnya dengan tahap kedua dan ketiga pada tahap konseling konvensional yang berisikan tentang identifikasi dan penetapan model permasalahan konseli, dan penetapan arah dan tujuan konseling. Model KIPAS terkesan terlalu humanis dalam memandang klien yang tergambar pada langkah pertama sesi wawancara konseling, yaitu kabar gembira. Tema-tema yang ditawarkan Model KIPAS sudah cukup komprehensif, namun belum menyentuh aspek religiusitas atau bidang keberagamaan yang menjadi salah satu corak khas kondisi psikososial masyarakat Indonesia

\section{DAFTAR RUJUKAN}

Cottone, R.R. (1992). Theories and Paradigms of Counseling and Psychotherapy. Massachusetts: Allyn $\&$ Bacoon, Inc.

Erford, B.T. (2015). 40 Techniques Every Counselor Should Know. New Jersey: Pearson Education, Inc.

Geldard, K \& Geldard, D. (2005). Practical Counseling Skills: An Integratif Approach.Basingstoke: Palgrave Macmillan.

Corey, Gerald (1991). Theory and Parctice of Counseling and Psychotherapy. California:Brooks/Cole Publishing Company.

Gibson \& Mitchel (2011).Introduction to Counseling and Guidance.Pearson Prentice Hall.

Hansen, J. C., Stevic, R. R., \& Warner, R. W. (1982). Counseling: Theory and Process (Vol. 23). Allyn \& Bacon.

Hariko, R. (2017). Landasan Filosofis Keterampilan Komunikasi Konseling. Jurnal Kajian Bimbingan dan Konseling. Vol. 2(2): 41-49

Hariko, R. (2016). Ilmu Bimbingan dan Konseling, Nilai dan Kesejahteraan Individu: Studi Literatur. Jurnal Konseling dan Pendidikan. Vol. 4 (2): 118-123.

Hossoubah, Z. (2007). Develoving Creative and Critical Thinking Skills (Terjemahan). Bandung: Yayasan Nuansa Cendia. 
Kartodirdjo, S. (1968). Segi-segi StrukturilHistoriografi Indonesia dalam LembaranSejarah. Yogyakarta: UGM.

Mappiare-AT, A. (2013a). Martabat Konselor Indonesia dalam Falsafah dan Kinerja Model KIPAS: Konseling Intensif Progresif Adaptif Struktur. Prosiding Kongres XII, Konvensi Nasional XVIII ABKIN dan Seminar Internasional Konseling, Denpasar Bali, 14 s.d 16 November 2013. Denpasar: Panitia Kongres XII, Konvensi Nasional BK XVIII.

Mappiare-AT, A. (2013b). Penguatan Layanan Bimbingan dan Konseling Melalui Model Konseling Intensif dan Progresif yang Adaptif terhadap Struktur (KIPAS). Proceeding Seminar Internasional Forum FIPJIP Se-Indonesia, Medan, 29-31 Oktober 2013. Medan: UNIMED Press.

Mappiare-AT, A. (2013c). Tipe-tipe Metode Riset Kualitatif: untuk Eksplanasi Sosial Budaya dan Bimbingan Konseling. Malang: Elang Mas bersama Prodi Bimbingan dan Konseling Fakultas Ilmu Pendidikan Universitas Negeri Malang.

Mappiare-AT, A. (2017). Meramu Model Konseling Berbasis Budaya Nusantara: KIPAS (Konseling Intensif Progresif Adaptif Struktur). Pidato Pengukuhan Jabatan Guru Besar dalam Bidang Ilmu Budaya Konseling pada Fakultas Ilmu Pendidikan. Disampaikan pada Sidang Terbuka Senat Universitas Negeri Malang pada Tanggal 28 Februari 2017.

McLeod, J. (2009). An Introduction to Counseling: 14th Edition. USA: McGraw-Hill.

Nelson-Jones, R. (2008). Introduction to Counselling Skills: Text and Activities. London: Sage Publication Ltd.

Neukrug, E. (2011). The World of the Counselor: An Introduction to the Counseling Profession. USA: Brooks/Cole.

Nizhamul, H.H. 2009. Kearifan Lokal Wanita Minangkabau.Diunggah pada tanggal 29 April 2017 dari https://bundokanduang.wordpress.com/page/9/

Palmer, Stephen. (2010). Introduction to Counseling and Psychotherapy: The Essential Guide. Sage Publication Ltd.

Prayitno. (1998) Konseling Pancawaskita: Kerangka Konseling Eklektik. Padang: IKIP Padang.

Setiawan, E. (2016). Kamus Besar Bahasa Indonesia (KBBI): Kamus versi online/daring (dalam jaringan). Diunggah dari http://kbbi.web.id/kritik

Shertzer, B., \& Stones, S.C. (1974). Fundamentals of Counseling. Boston: Houghton Mifflin Company.

Syam, M.N. (1988) Filsafat Pendidikan Pancasila: Sebagai Sumber dan Dasar Pembinaan Manusia Indonesia Seutuhnya. Surabaya: Usaha Nasional. 